\title{
Unique Properties of Polyphenol Stilbenes in the Brain: More than Direct Antioxidant Actions; Gene/Protein Regulatory Activity
}

\author{
Sylvain Doré \\ Johns Hopkins University, School of Medicine, Baltimore, Md., USA
}

\author{
Key Words \\ Bilirubin - Biliverdin - Blood flow $\cdot$ Carbon monoxide • \\ Hemin · Iron
}

\begin{abstract}
The 'French Paradox' has been typically associated with moderate consumption of wine, especially red wine. A polyphenol 3,4',5-trihydroxy-trans-stilbene (a member of the non-flavonoids family), better known as resveratrol, has been purported to have many health benefits. A number of these valuable properties have been attributed to its intrinsic antioxidant capabilities, although the potential level of resveratrol in the circulation is likely not enough to neutralize free radical scavenging. The brain and the heart are uniquely vulnerable to hypoxic conditions and oxidative stress injuries. Recently, evidence suggests that resveratrol could act as a signaling molecule within tissues and cells to modulate the expression of genes and proteins. Stimulation of such proteins and enzymes could explain some the intracellular antioxidative properties. The modulation of genes could suffice as an explanation of some of resveratrol's cytoprotective actions, as well as its influence on blood flow, cell death, and inflammatory cascades. Resveratrol stimulation of the expression of heme oxygenase is one example. Increased heme oxygenase activity has led to significant
\end{abstract}

protection against models of in vitro and in vivo oxidative stress injury. Resveratrol could provide cellular resistance against insults; although more work is necessary before it is prescribed as a potential prophylactic in models of either acute or chronic conditions, such as stroke, amyotrophic lateral sclerosis, Parkinson, Alzheimer, and a variety of age-related vascular disorders.

Copyright $\subset 2005$ S. Karger AG, Basel

The 'French Paradox,' so named after a population studied in France, is defined by a low incidence of cardiovascular problems despite a diet that is relatively high in saturated fat [1]. Because of the typical levels of wine intake of the French, it has also been postulated that a moderate consumption of red wine could be associated with this paradox. A vast amount of recent literature proposes that it is the polyphenols in red wine that provide the beneficial effect, mainly attributable to their potential to act as antioxidants. These polyphenols are divided into two main categories: flavonoids and non-flavonoids. The flavonoids, found in natural extracts of plants and fruits, are considered to be the most abundant polyphenols, whereas the non-flavonoid stilbenes are considered to be a minor class. The naturally occurring polyphenol stilbene, resveratrol (3,4',5-trihydroxy-trans-stilbene), has been proposed to possess most of the beneficial health ef-

\section{KARGER}

(C) 2005 S. Karger AG, Basel

Fax +41613061234

E-Mail karger@karger.ch

www.karger.com
Accessible online at: www.karger.com/nsg
Sylvain Doré, $\mathrm{PhD}$

Johns Hopkins University, School of Medicine

ACCM Department, Neuro Research Division, 720 Rutland Ave

Ross Research Building 364-365, Baltimore, MD 21205 (USA)

Tel. +1 410614 4859, Fax +1 410955 7271, E-Mail sdore@jhmi.edu 


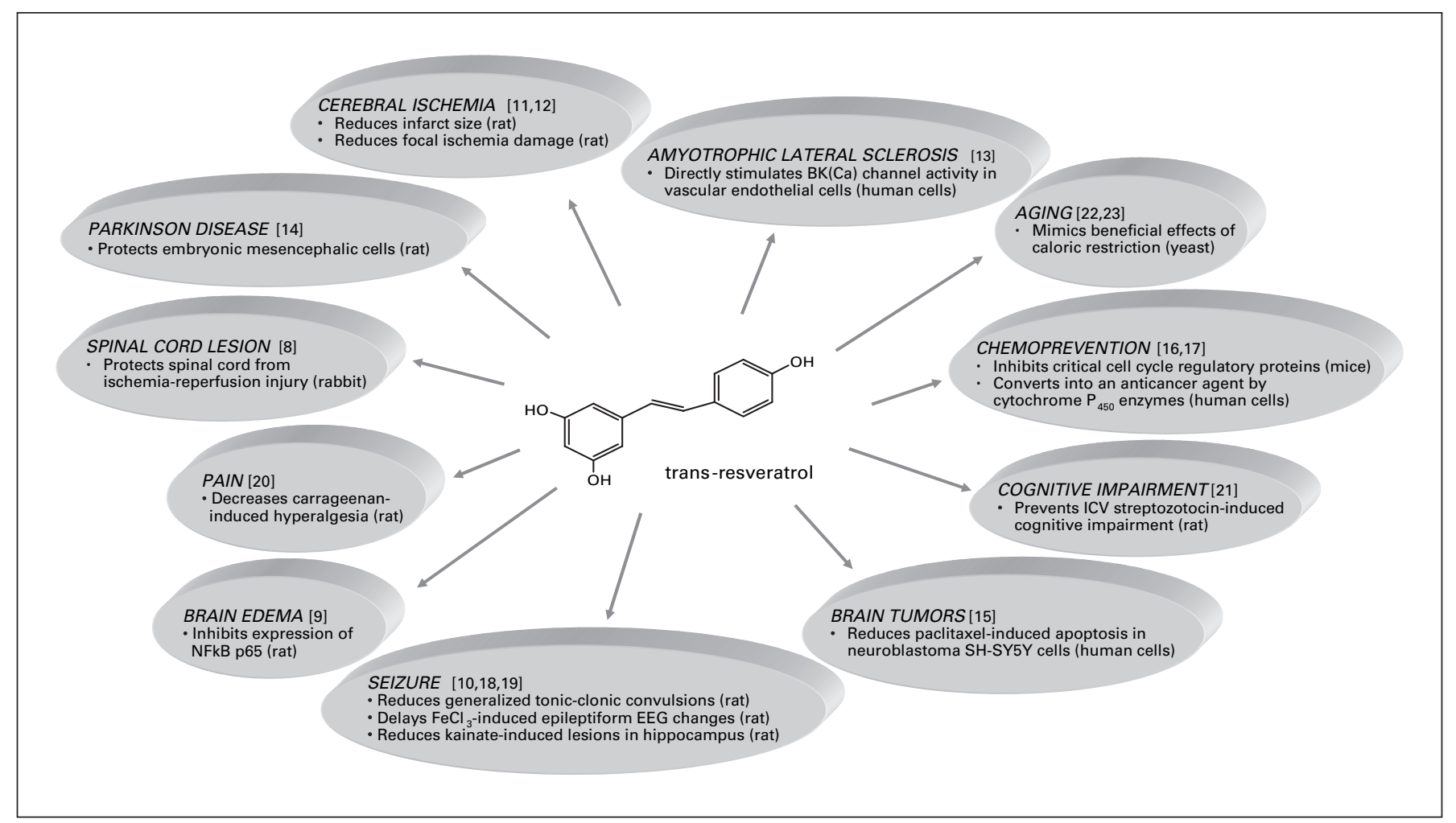

Fig. 1. Experimental neurologic benefits of resveratrol.

fects of red wine, considering that resveratrol is mainly found in the skin of the grapes, and the skin and seeds are generally not used in processing white wines. Consequently, it has been proposed that resveratrol would potentially be the most active ingredient [2-5]. Given all of this, the antioxidant properties of red wine, then, must be associated with the actions of resveratrol, and we propose that the protective properties are likely due to a unique cascade of intracellular events leading to activation of unique antioxidant pathways. This hypothesis is being proposed, taking into consideration that the modest amount of resveratrol in the blood is not likely to reach a high enough plasmatic level to neutralize free radicals. Consequently, resveratrol is likely to stimulate an intracellular signaling pathway, leading to cytoprotection.

As represented here, several genes and proteins have been shown to be potential targets for resveratrol modulation. Heme oxygenase (HO) is a possible candidate. We have shown that resveratrol is a potent inducer of $\mathrm{HO}$ protein levels, activity, and cytoprotection [6]. HO's main function is to cleave heme (Iron-Protoporphyrin-IX), which then liberates iron, generating carbon monoxide and biliverdin, which is rapidly converted to bilirubin.
By degradation of heme, a prooxidant, into biliverdin/ bilirubin, antioxidants, modulation of $\mathrm{HO}$ activity and levels would seem to be cytoprotective against free radical damage. Using in vitro and in vivo models, we have also shown that $\mathrm{HO}$ can be neuroprotective [7]. In addition, $\mathrm{HO}$ and its metabolites have been associated with antiapoptotic and antiinflammatory actions and are known to have a vasodilatory effect.

Several other enzymatic systems have been suggested to be either directly or indirectly modified by different members of the stilbene family. Here, we propose that protective properties of $\mathrm{HO}$ are the mechanisms that provide the brain's resistance to a variety of neurologic stresses. Resveratrol has been shown to have a unique effect on neuronal cell death and inflammatory processes, which are all important therapeutic targets in the development of either acute and/or chronic neurodegenerative diseases [8-10]. These vascular properties become especially important when considering that reduction in cerebral blood flow $(\mathrm{CBF})$, followed by a reperfusion phase, is likely to affect specific neurons and/or the cell types that are especially vulnerable to free radical damage. Consequently, preventing cell death is likely to have a beneficial 
effect on the rate of neuroinflammation and its consequences. Considering all of this together, one can make a valid hypothesis that polyphenol stilbenes can precondition neurons against induced stress damage.

Figure 1 contains a list of potential neurologic benefits associated with models of neurologic diseases treated with resveratrol. Of importance is the fact that resveratrol has been shown to be protective in several species. Following publication in Science and Nature of initial reports that suggested a potential biologic role of resveratrol [24, 25], more than 900 original research articles have been published to support the beneficial effect of resveratrol.

It is somewhat paradoxical that such a simple, natural component, extracted from plants and fruits, can have such a variety of actions. The flavonoids constitute the majority of phenols in red wine and are mainly divided into three classes: the flavanols, the flavonols, and the anthocyanins. The known flavonoids (hydroxycinnamic acids, benzoic acids, and stilbenes) are less abundant, and the stilbenes are only a minor class of the known flavonoids.

Interestingly, during the production of red wine, complex sugars from the grapes are fermented into alcohol, and it is believed that alcohol would be considered a good solvent for extracting polyphenols from the skins and seeds. Considering that resveratrol is mainly found in the skin of the grapes, it has been reported that the amount of phenols within white wine would be much less than in red wine. Although the reported amounts of resveratrol in wine vary, they suggest that approximately $7 \mathrm{mg} / \mathrm{l}$ are present in most reds, as compared to $0.5 \mathrm{mg} / \mathrm{l}$ in whites $[26,27]$. For purposes of comparison, the flavonoid concentrations in red wine have been in the range of 1,300 $1,500 \mathrm{mg} / \mathrm{l}$. Once again, considering all of the beneficial properties of resveratrol, its minimal amount available in wine, if active, is likely to be mediated via activation of intracellular pathways.

It is interesting to note, also, that resveratrol exists in two isomers, the cis and the trans, as shown in figure 2. Both of these are found in wine, and, although it appears that only the trans isomer is found in grapes, direct light could cause its isomerization from trans to $c i s$. In our preliminary observations in neurons, we indicated that the active isoform would be mainly the trans resveratrol.

The fact that resveratrol, a simple active ingredient, which has been proposed to be responsible for the rationale behind the French Paradox, is present in such small amounts in wine or juice, and the theory concerning its bioactivity by its direct antioxidant capacity deserve reconsideration. Thus, it led us to hypothesize the activa-

Unique Properties of Polyphenol Stilbenes in the Brain

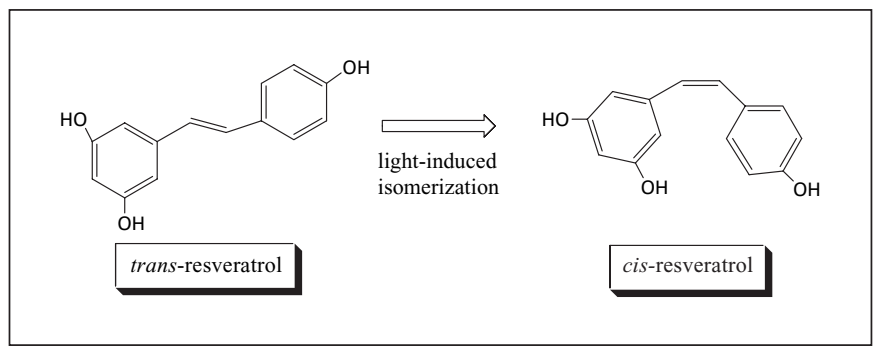

Fig. 2. UV-light-induced isomerization of trans- to cis-resveratrol.

tion of an antioxidant intracellular pathway. Considering the direct antioxidant properties associated with resveratrol and taking into account the absorption rate and modifications/conjugations, one would have to consume liters of these drinks in order to achieve the necessary plasmatic molar ratio to neutralize the free radicals and achieve the beneficial health effects. To highlight the variability of resveratrol's effects, figure 3 shows the intracellular consequences of cells treated with the maximal concentration of $25 \mu M$, although the list is not exhaustive. We eliminated experiments in which the concentration was higher than $25 \mu M$. We believe that it is reasonable to think that a level $\leq 25 \mu M$ could potentially be achieved under normal conditions and not typically under pharmacologic conditions.

Figure 3 shows the expression regulated by resveratrol of different genes and proteins and describes some of the potential functions. Living organisms under aerobic conditions are continuously exposed to potential damage caused by reactive oxygen species (ROS). ROS are produced naturally during normal cellular activity and mitochondrial function. In addition, induced stress is likely to modify these normal functions and simulate the generation of free radical damage. Many of the studies using polyphenols have required pretreatment with resveratrol to exert these beneficial biologic functions. Such pretreatment would require either an increase in the concentration of this polyphenol or stimulate a cascade leading to activation of an endogenous antioxidant system. This activation is critically important to cytoprotection in tissue with a weak, endogenous, antioxidant system. The heart and the brain are two unique examples of tissues with weak defenses, as evidenced by infarct damage following ischemia/reperfusion.

Considering the antioxidant properties associated with resveratrol, we have concentrated on the neuroprotective effect of resveratrol and the possibility that this 


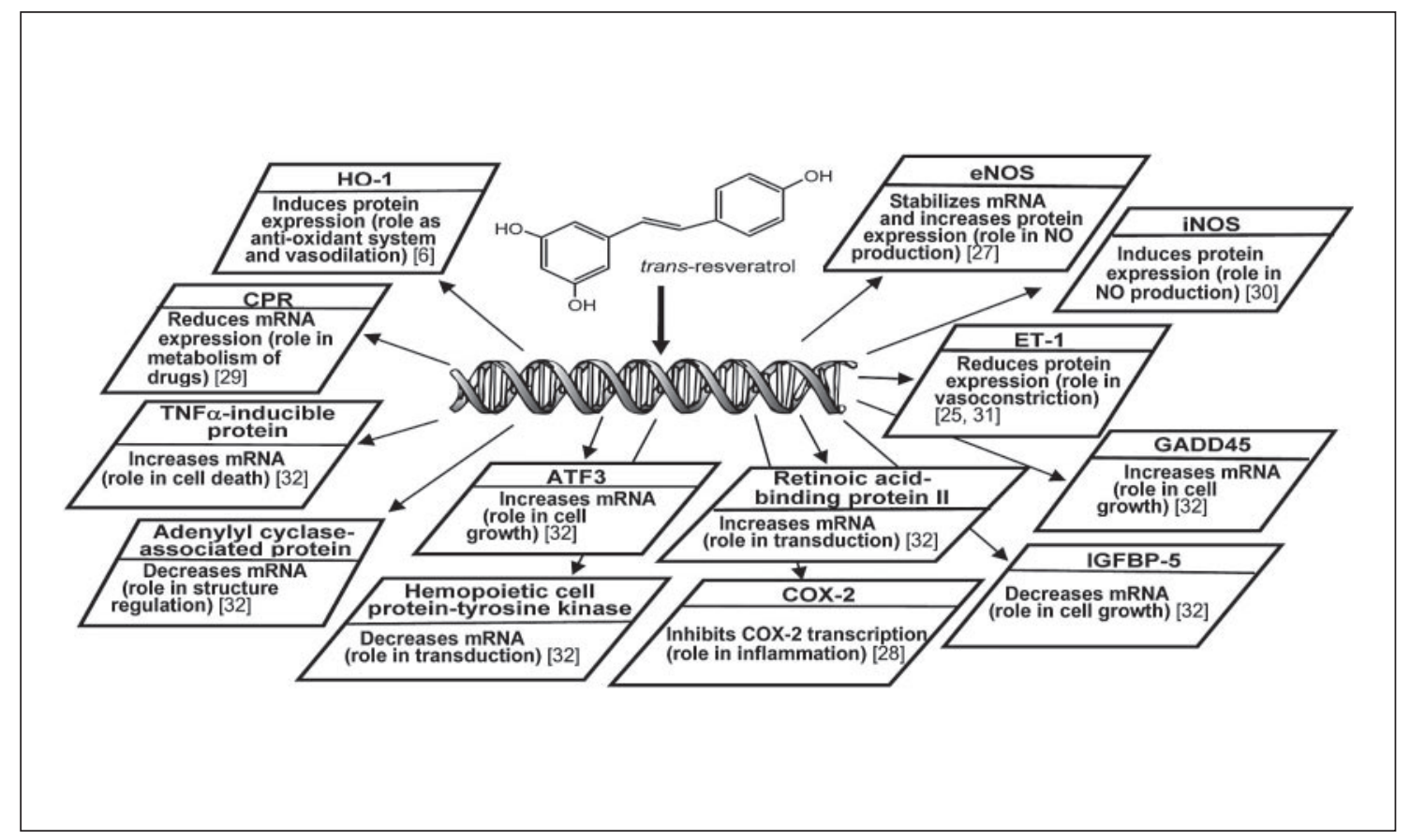

Fig. 3. Example of resveratrol-regulated genes/proteins affected in cells $(<25 \mu M)$. HO1 = Heme oxygenase 1 ; COX-2 = cyclooxygenase 2 ; eNOS = endothelial nitric oxide synthase; iNOS = inducible nitric oxide synthase; ET-1 = endothelin-1; GADD45 = growth-arrest- and DNA-damage-induced protein 45; TNF $\alpha=$ tumor necrosis factor-alpha; ATF3 = activating transcription factor 3; IGFBP = insulin-like growth factor-binding protein.

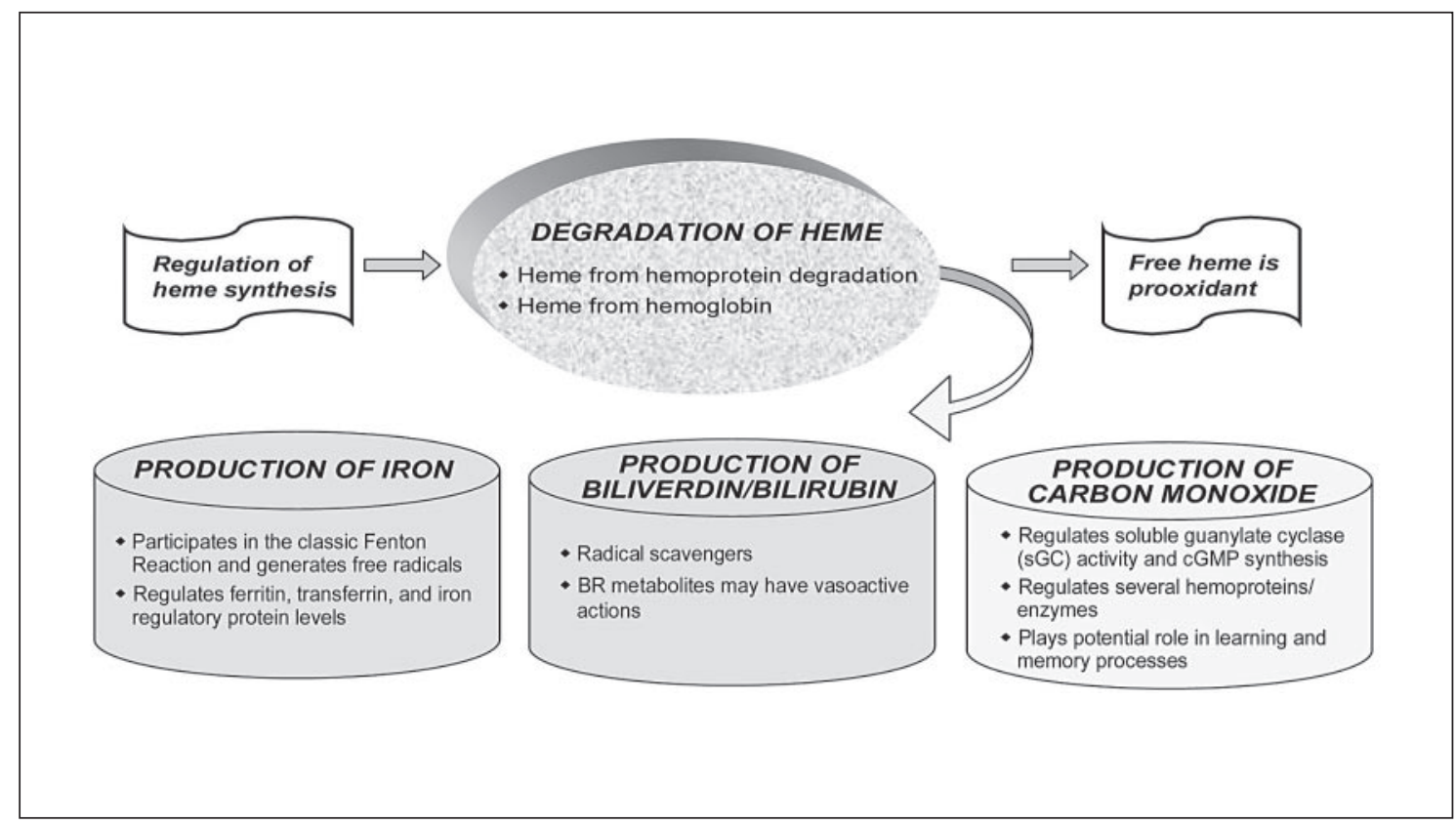

Fig. 4. Example of potential outcomes from gene/protein regulation (i.e., HO1) and potential enzymatic role in the brain. Note: This list of potential actions would occur at physiologic levels, while abnormal or pharmacologic levels of these compounds could have deleterious effects. 
Fig. 5. Resveratrol mediates heme degradation by induction of heme oxygenase levels.

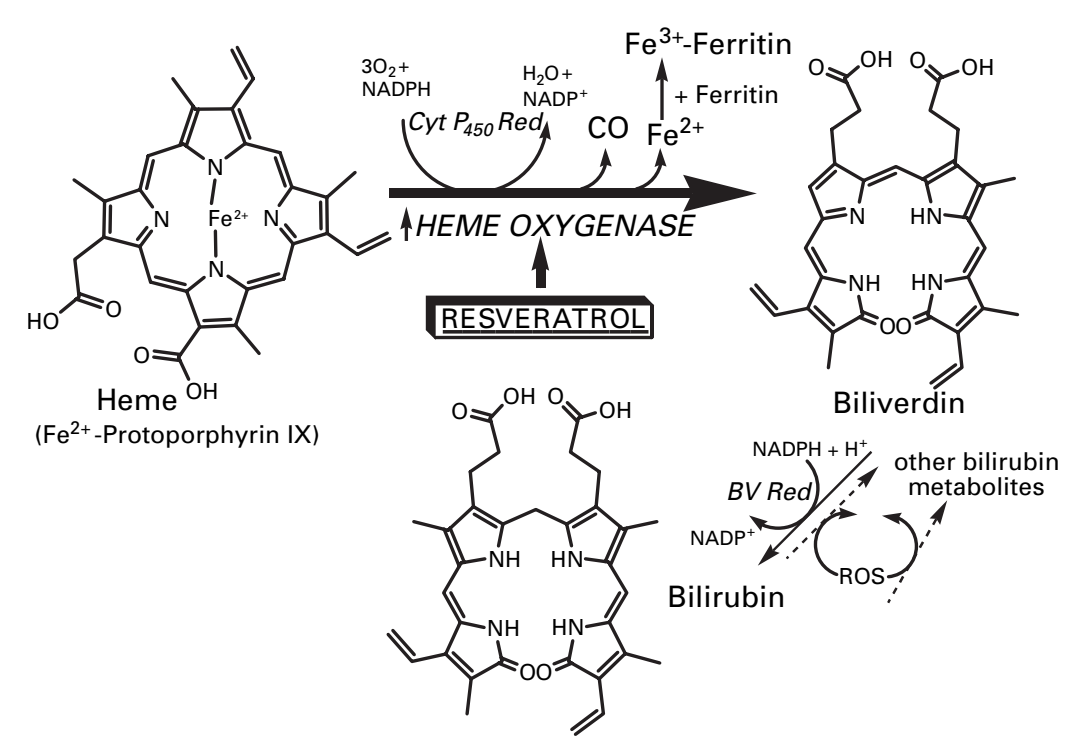

pathway could involve the induction of an antioxidant system, such as heme oxygenase. Regulation of $\mathrm{HO}$ activity has been shown to be protective in acute and/or chronic neurodegenerative conditions. Figure 4 summarizes some of the potential outcomes of regulation of the $\mathrm{HO}$ protein and its activity.

As mentioned above, $\mathrm{HO}$ catalyzes the degradation of heme, which is mainly a prooxidant, into iron, biliverdin/ bilirubin, and carbon monoxide (fig. 5). Two isoforms of $\mathrm{HO}$ have been isolated and characterized [7, 33-35]. A third isoform has been reported, although it does not seem to be translated into a protein [36]. HO1, the first to be isolated [34], is the inducible enzyme and appears to be concentrated mainly in the liver and spleen, an understandable observation considering the high turnover of hemoglobin, which has heme in its core. Under basal conditions, $\mathrm{HO} 1$ is barely detectable in the brain, although several reports suggest that, under a variety of stimuli, it can be induced within brain tissue [37-48]. $\mathrm{HO} 2$ is an isoform that is constitutively expressed and appears to be concentrated mainly in the brain and testis [48]. Its protein expression level appears to be extremely stable, which is likely to respond to normal cellular homeostasis.

Regulation of the $\mathrm{HO} 1$ protein and its activity has elicited a great deal of interest. Regulation of $\mathrm{HO} 1$ has been suggested to be in response to many cellular and organ stresses, in order to defend against disruption of any system homeostasis. HO1 has been suggested to have different functions in the brain. It is one of the heat shock proteins, which are stress proteins that are induced in different cells and following different stimuli [37], including hypothermia [38], global ischemia [41], subarachnoid hemorrhage [42], Parkinson disease [47], Alzheimer disease $[39,40]$, and several other acute and chronic neurologic conditions [43-46].

In a model of transient ischemia, we and others have shown that HO mRNA and proteins are induced [43]. Reports have indicated that induction of $\mathrm{HO}$ proteins in neurons would be protective [49], and our preliminary data indicate that resveratrol could induce HO levels within neurons, potentially affording neuroprotection. Consequently, we believe that modulation of HO levels and its activity could be a pathway by which resveratrol present in red wine or other concentrated extracts could potentially protect the nervous system against induced oxidative stress damage. Many heme-containing enzymes are located in the mitochondria, the cytosol, and the endoplasmic reticulum; and they presumably undergo rapid turnover during oxidative stress. HO is the main enzyme, which can degrade free heme, a prooxidant, and maintain levels that would not reach toxicity. Following an ischemic event, tissue injury has been proposed to be mainly due to increased oxidative stress by free radicals 
generated during the reperfusion phase. We have previously shown that the infarct volume in $\mathrm{HO} 2$ knockout $\left(\mathrm{HO}^{-/-}\right)$mice versus wild-type (WT) mice after stroke is approximately double. $\mathrm{HO} 2$ is the isoform present under normal basal conditions. Consequently, increasing the activity of heme oxygenase is likely to be protective in stroke.

Interestingly, the group led by Maines has demonstrated significant reduction in infarct size after stroke in a transgenic mouse model on which $\mathrm{HOl}$ was over-expressed using a neuron-specific promoter [50]. In addition, we have recently accumulated evidence suggesting that pre-treatment with resveratrol would be a most potent inducer of $\mathrm{HO} 1$ in mouse primary neuronal cultures, that it would be sufficient to prevent induced neurotoxicity, and that this neuroprotection was significantly attenuated by the use of a heme oxygenase inhibitor [51]. All together, these results suggest that an increase in $\mathrm{HO} 1$ protein levels and its activities within neurons is likely to provide neuroprotection and promote cell survival.

\section{Heme}

Heme metabolism is a crucial metabolic process. It has been postulated that free heme can rapidly be generated from an induced turnover of heme-containing proteins/ enzymes, for example, catalase, glutathione peroxidase, superoxide dismutase, cytochrome, guanylate cyclase, nitric oxide synthase, etc. It has been further suggested that during hypoxia, ischemic injury could trigger significant amounts of heme being released into the intracellular pool. When stimulation of these hemoproteins is degraded, heme becomes free; probably not salvaged, it should be rapidly degraded. $\mathrm{HO}$ is the enzyme that can rapidly cleave prooxidant through heme and limit its capacity to enter into generation of a free radical cycle - notably, through its iron molecule. Consequently, HO could be considered an antioxidant enzyme by degradation of the prooxidant heme. Our previous observations indicate that resveratrol could specifically induce $\mathrm{HO} 1$ within neurons and potentially protect cells against oxidative stress injury. Such a pathway is an interesting target for resveratrol, considering that it can regulate the redox state of the cell and prevent cells from dying through an oxidative stress-induced cascade.

\section{Iron}

Degradation of heme by HO1 also generates a molecule of iron. Evidence suggests that regulation of HO1 protein levels could modulate the level of intracellular heme. It is postulated that $\mathrm{HO}$ can stimulate the efflux of iron outside the cell [52]. Homeostasis of iron is a key factor in controlling cell toxicity. As one example, free iron has been considered to be a key ingredient in the Fenton reaction, in which by reacting with $\mathrm{H}_{2} \mathrm{O}_{2}$, it generates free radicals. Regulation of cellular homeostasis of iron is a complex and tightly regulated system. It is regulated by many proteins, a number of which are still under extensive characterization. Rapid upregulation of $\mathrm{HO} 1$ by resveratrol in neurons could potentially directly affect the intracellular iron level.

It has been previously demonstrated that decrease in HO1 activity would be sufficient to change its iron level within the cell. For example, by using $\mathrm{HO}^{-/-}$mice, it has been shown that iron accumulates in several organs [53]. In addition, numerous iron-binding proteins are regulated by intracellular levels of free iron [54]. As an example, ferritin in the cell can sequester numerous molecules of iron, and its intracellular level is tightly regulated to free iron.

Therapeutic implications of controlling iron levels within tissues or within cells are numerous. As an example, administration of desferoxamine, a trivalent iron chelator, over a 2-year period slows the clinical progression of symptoms associated with Alzheimer disease [55]. Further study may bear out that the regulation of $\mathrm{HO} 1$ levels also regulates the cellular iron homeostasis. Interestingly, very little has been investigated regarding the potential role of resveratrol in regulating iron and determining its potential effect in neurologic disorders.

\section{Carbon Monoxide}

Carbon monoxide $(\mathrm{CO})$ is a gas that is almost exclusively generated in cells by degradation of heme by heme oxygenase $[56,57]$. In that it is a gas, carbon monoxide can travel freely through intracellular and extracellular compartments. The CO literature is vast and complex with many controversies that have yet to be resolved [5863]. $\mathrm{CO}$ is better known to be toxic at high levels. It can also cause death [64]. Interestingly, in the recent literature, low concentrations of $\mathrm{CO}$ have been suggested to be protective. Although $\mathrm{CO}$ has an affinity slightly lower to its homologue, nitric oxide (NO), which is another gas, it appears that its half-life would be significantly longer. Such an observation could allow carbon monoxide, by binding to heme moiety present on several key enzymes, to modulate their function [65]. Within the cell, physiologic/normal levels of $\mathrm{CO}$ generated from degradation of intracellular heme are likely to have multiple biologic functions on several heme-containing proteins. For example, $\mathrm{CO}$ has been shown to act as a vasodilator by po- 
tentially binding with soluble guanylate cyclase (sGC) and modulating its vasoactive activities. It can act on calcium-activated potassium channels $\left(\mathrm{K}_{\mathrm{Ca}}\right.$ channels) and regulate their opening $[66,67]$. $\mathrm{CO}$ has also been recently reported to have specific antiapoptotic and antiinflammatory actions $[68,69]$. Rapid induction of $\mathrm{HO} 1$ could be a means by which resveratrol can increase $\mathrm{CO}$ levels within physiologic concentrations and allow cells and tissue to benefit from many of CO's biologic actions, especially in scenarios in which blood flow is reduced and cell survival is compromised.

\section{Bilirubin}

Bilirubin is known for its toxicity, at high micromolar concentrations, in the central nervous system (CNS), especially in neonates. Although under physiologic concentrations, bilirubin can act as an endogenous antioxidant [70, 71]. In testing a series of antioxidants, bilirubin was shown to have significant superoxide and hydroxyl radical scavenger activity [72]. Using an animal model of hyperbilirubinemia, a protective effect against cerebral ischemia was demonstrated. We have also observed, using primary hippocampal and cortical neuronal cultures, that bilirubin can be protective at low concentrations [73, 74]. Moreover, in previous observations on the potential role of $\mathrm{HO}$ in Alzheimer disease pathology [39, 75], levels of bilirubin derivatives in the cerebral spinal fluid were reported to be significantly increased in brains of AD patients as compared to control [76]. An increase in HO1 within AD brains was reported. Increased HO1 levels could potentially increase the bilirubin level within a physiologic range, and such a pathway could explain some of the antioxidant properties associated with resveratrol in relation to neurologic deficits in age-related dementia.

Figure 6 briefly summarizes some of the neurologic disorders that can be beneficially affected by the regulation of $\mathrm{HO}$ activity. Regulation of genes by resveratrol, such as in the case of $\mathrm{HO} 1$, presents a potential mechanism by which its prophylactic use might be considered, under either acute or chronic neurologic disorders. For example, under ischemic stroke conditions, reperfusion frequently occurs after focal ischemia, particularly in the case of cerebral embolism and transient ischemic attack. These can be warning signs of impending stroke. Recurrence is a prevalent phenomenon in patients who have suffered one episode of stroke. Therefore, availability of a prophylactic approach in these patients is an important goal of preventive medicine. Reports that coronary heart disease appears to be reduced in patients who chroni-

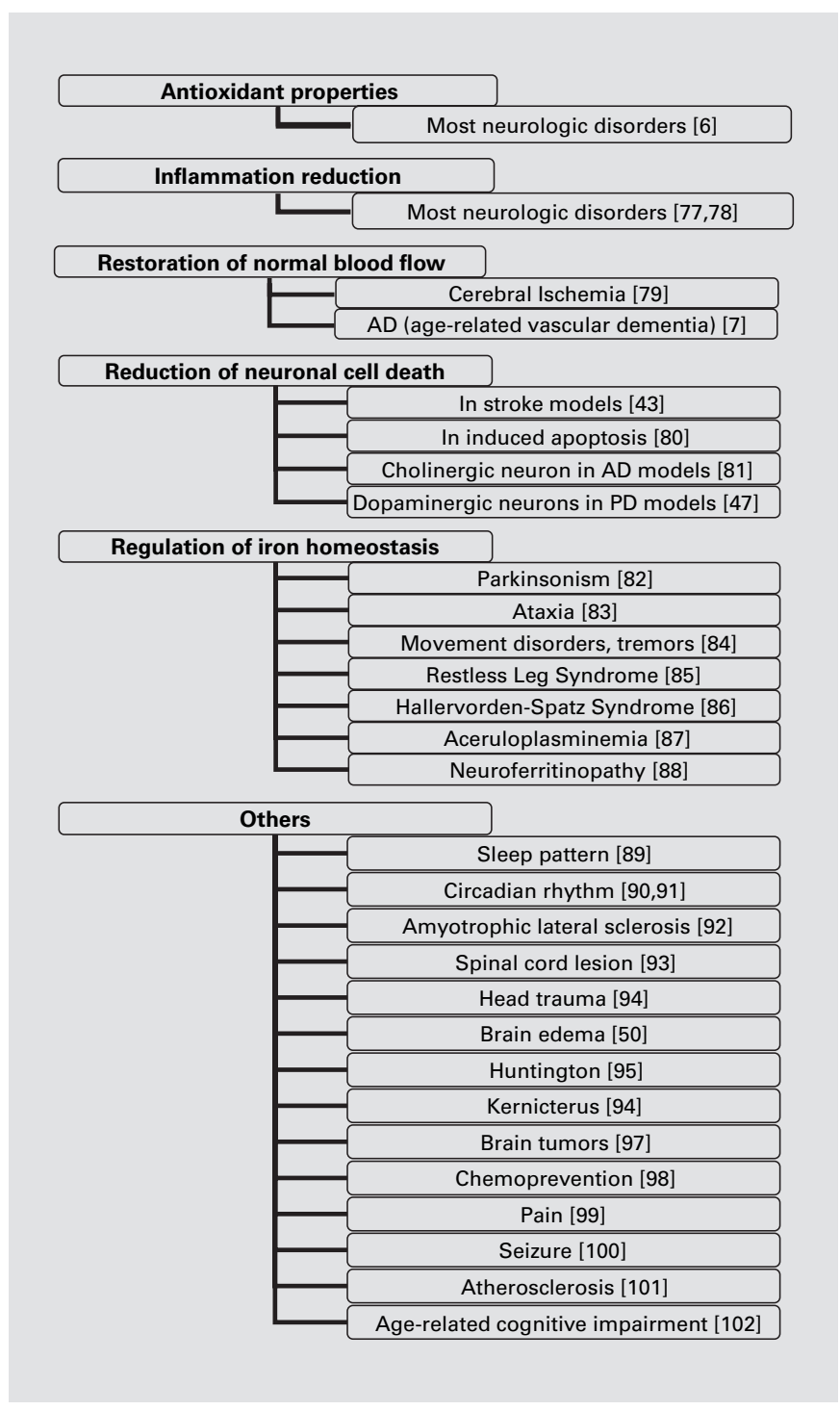

Fig. 6. Non-exhaustive list of potential neurologic benefits of resveratrol-regulating $\mathrm{HO} 1$.

cally consume moderate amounts of red wine support the prospect of a prophylactic role for resveratrol. Consequently, a better understanding of the mechanisms by which polyphenols and red wine can protect against ischemic and toxic insults would be of great interest.

\section{Acknowledgements}

This work is supported in part by the NIH grants (AA014911 and AT002113), the Wine Institute, and the ABMR Foundation. The author would like to thank Tzipora Sofare, MA, for her assistance in preparing the manuscript. 


\section{References}

1 Renaud S, de Lorgeril M: Wine, alcohol, platelets, and the French paradox for coronary heart disease. Lancet 1992;339:1523-1526.

-2 Sato M, Ray PS, Maulik G, Maulik N, Engelman RM, Bertelli AA, Bertelli A, Das DK: Myocardial protection with red wine extract. J Cardiovasc Pharmacol 2000;35:263-268.

-3 Soleas GJ, Diamandis EP, Goldberg DM: Resveratrol: A molecule whose time has come? And gone? Clin Biochem 1997;30:91-113.

-4 Goldberg D, Tsang E, Karumanchiri A, Diamandis E, Soleas G, Ng E: Method to assay the concentrations of phenolic constituents of biological interest in wines. Anal Chem 1996;68: 1688-1694.

5 Celotti E, Ferrarini R, Zironi R, Conte LS: Resveratrol content of some wines obtained from dried Valpolicella grapes: Recioto and Amarone. J Chromatogr [A] 1996;730:47-52.

-6 Zhuang H, Kim YS, Koehler RC, Doré S: Potential mechanism by which resveratrol, a red wine constituent, protects neurons. Ann NY Acad Sci 2003;993:276-286.

7 Doré S: Decreased activity of the antioxidant heme oxygenase enzyme: Implications in ischemia and in Alzheimer's disease. Free Radic Biol Med 2002;32:1276-1282.

-8 Kiziltepe U, Turan NN, Han U, Ulus AT, Akar F: Resveratrol, a red wine polyphenol, protects spinal cord from ischemia-reperfusion injury. J Vasc Surg 2004;40:138-145.

-9 Wang YJ, He F, Li XL: The neuroprotection of resveratrol in the experimental cerebral ischemia. Zhonghua Yi Xue Za Zhi 2003;83:534536.

10 Virgili M, Contestabile A: Partial neuroprotection of in vivo excitotoxic brain damage by chronic administration of the red wine antioxidant agent, trans-resveratrol in rats. Neurosci Lett 2000;281:123-126.

11 Huang SS, Tsai MC, Chih CL, Hung LM, Tsai SK: Resveratrol reduction of infarct size in Long-Evans rats subjected to focal cerebral ischemia. Life Sci 2001;69:1057-1065.

-12 Sinha K, Chaudhary G, Gupta YK: Protective effect of resveratrol against oxidative stress in middle cerebral artery occlusion model of stroke in rats. Life Sci 2002;71:655-665.

13 Wu SN: Large-conductance $\mathrm{Ca}^{2+}$-activated $\mathrm{K}^{+}$ channels: Physiological role and pharmacology. Curr Med Chem 2003;10:649-661.

-14 Karlsson J, Emgard M, Brundin P, Burkitt MJ: Trans-resveratrol protects embryonic mesencephalic cells from tert-butyl hydroperoxide: Electron paramagnetic resonance spin trapping evidence for a radical scavenging mechanism. J Neurochem 2000;75:141-150.

- 15 Nicolini G, Rigolio R, Scuteri A, Miloso M, Saccomanno D, Cavaletti G, Tredici G: Effect of trans-resveratrol on signal transduction pathways involved in paclitaxel-induced apoptosis in human neuroblastoma SH-SY5Y cells. Neurochem Int 2003;42:419-429.
16 Reagan-Shaw S, Afaq F, Aziz MH, Ahmad N: Modulations of critical cell cycle regulatory events during chemoprevention of ultraviolet B-mediated responses by resveratrol in SKH-1 hairless mouse skin. Oncogene 2004;23:51515160.

17 Potter GA, Patterson LH, Wanogho E, Perry PJ, Butler PC, Ijaz T, Ruparelia KC, Lamb JH, Farmer PB, Stanley LA, Burke MD: The cancer preventative agent resveratrol is converted to the anticancer agent piceatannol by the cytochrome P450 enzyme CYP1B1. Br J Cancer 2002;86:774-778.

18 Gupta YK, Chaudhary G, Srivastava AK: Protective effect of resveratrol against pentylenetetrazole-induced seizures and its modulation by an adenosinergic system. Pharmacology 2002;65:170-174.

19 Gupta YK, Chaudhary G, Sinha K, Srivastava AK: Protective effect of resveratrol against intracortical $\mathrm{FeCl}_{3}$-induced model of posttraumatic seizures in rats. Methods Find Exp Clin Pharmacol 2001;23:241-244.

20 Gentilli M, Mazoit JX, Bouaziz H, Fletcher D, Casper RF, Benhamou D, Savouret JF: Resveratrol decreases hyperalgesia induced by carrageenan in the rat hind paw. Life Sci 2001;68: 1317-1321.

21 Sharma M, Gupta YK: Chronic treatment with trans resveratrol prevents intracerebroventricular streptozotocin induced cognitive impairment and oxidative stress in rats. Life Sci 2002; 71:2489-2498.

22 Howitz KT, Bitterman KJ, Cohen HY, Lamming DW, Lavu S, Wood JG, Zipkin RE, Chung P, Kisielewski A, Zhang LL, Scherer B, Sinclair DA: Small molecule activators of sirtuins extend Saccharomyces cerevisiae lifespan. Nature 2003;425:191-196.

23 Wood JG, Rogina B, Lavu S, Howitz K, Helfand SL, Tatar M, Sinclair D: Sirtuin activators mimic caloric restriction and delay ageing in metazoans. Nature 2004;430:686-689.

-24 Jang M, Cai L, Udeani GO, Slowing KV, Thomas CF, Beecher CW, Fong HH, Farnsworth NR, Kinghorn AD, Mehta RG, Moon RC, Pezzuto JM: Cancer chemopreventive activity of resveratrol, a natural product derived from grapes. Science 1997;275:218-220.

25 Corder R, Douthwaite JA, Lees DM, Khan NQ, Viseu Dos Santos AC, Wood EG, Carrier MJ: Endothelin-1 synthesis reduced by red wine. Nature 2001;414:863-864.

26 Ribeiro de Lima MT, Waffo-Teguo P, Teissedre PL, Pujolas A, Vercauteren J, Cabanis JC, Merillon JM: Determination of stilbenes (trans-astringin, cis- and trans-piceid, and cisand trans-resveratrol) in Portuguese wines. J Agric Food Chem 1999;47:2666-2670.

27 Wallerath T, Deckert G, Ternes T, Anderson $\mathrm{H}, \mathrm{Li} \mathrm{H}$, Witte K, Forstermann U: Resveratrol, a polyphenolic phytoalexin present in red wine, enhances expression and activity of endothelial nitric oxide synthase. Circulation 2002;106:1652-1658.
28 Subbaramaiah K, Chung WJ, Michaluart P, Telang N, Tanabe T, Inoue H, Jang M, Pezzuto JM, Dannenberg AJ: Resveratrol inhibits cyclooxygenase- 2 transcription and activity in phorbol ester-treated human mammary epithelial cells. J Biol Chem 1998;273:2187521882.

29 Cheung CY, Chen J, Chang TK: Evaluation of a real-time polymerase chain reaction method for the quantification of CYP1B1 gene expression in MCF-7 human breast carcinoma cells. J Pharmacol Toxicol Methods 2004;49:97104.

30 Imamura G, Bertelli AA, Bertelli A, Otani H, Maulik N, Das DK: Pharmacological preconditioning with resveratrol: An insight with iNOS knockout mice. Am J Physiol Heart Circ Physiol 2002;282:H1996-H2003.

- 31 Liu JC, Chen JJ, Chan P, Cheng CF, Cheng TH: Inhibition of cyclic strain-induced endothelin-1 gene expression by resveratrol. Hypertension 2003;42:1198-1205.

32 Shi T, Liou LS, Sadhukhan P, Duan ZH, Novick AC, Hissong JG, Almasan A, DiDonato JA: Effects of resveratrol on gene expression in renal cell carcinoma. Cancer Biol Ther 2004;3:1538-4047.

33 Ewing JF, Maines MD: Histochemical localization of heme oxygenase-2 protein and mRNA expression in rat brain. Brain Res Brain Res Protoc 1997; 1:165-174.

-34 Shibahara S, Muller R, Taguchi H, Yoshida T: Cloning and expression of cDNA for rat heme oxygenase. Proc Natl Acad Sci USA 1985;82: 7865-7869.

35 Maines MD: The heme oxygenase system: A regulator of second messenger gases. Annu Rev Pharmacol Toxicol 1997;37:517-554.

36 Zhuang H, Pin S, Li X, Doré S: Regulation of heme oxygenase expression by cyclopentenone prostaglandins. Exp Biol Med 2003;228:499505.

37 Ewing JF, Maines MD: Rapid induction of heme oxygenase 1 mRNA and protein by hyperthermia in rat brain: Heme oxygenase 2 is not a heat shock protein. Proc Natl Acad Sci USA 1991;88:5364-5368.

38 Ewing JF, Haber SN, Maines MD: Normal and heat-induced patterns of expression of heme oxygenase-1 (HSP32) in rat brain: Hyperthermia causes rapid induction of mRNA and protein. J Neurochem 1992;58:1140-1149.

- 39 Schipper HM, Cisse S, Stopa EG: Expression of heme oxygenase-1 in the senescent and Alzheimer-diseased brain. Ann Neurol 1995;37: 758-768.

40 Smith MA, Kutty RK, Richey PL, Yan SD, Stern D, Chader GJ, Wiggert B, Petersen RB, Perry G: Heme oxygenase-1 is associated with the neurofibrillary pathology of Alzheimer's disease. Am J Pathol 1994;145:42-47. 
-41 Takeda A, Kimpara T, Onodera H, Itoyama Y, Shibahara S, Kogure K: Regional difference in induction of heme oxygenase-1 protein following rat transient forebrain ischemia. Neurosci Lett 1996;205:169-172.

42 Kuroki M, Kanamaru K, Suzuki H, Waga S, Semba R: Effect of vasospasm on heme oxygenases in a rat model of subarachnoid hemorrhage. Stroke 1998;29:683-688; discussion 688-689.

-43 Doré S, Sampei K, Goto S, Alkayed NJ, Guastella D, Blackshaw S, Gallagher M, Traystman RJ, Hurn PD, Koehler RC, Snyder SH: Heme oxygenase-2 is neuroprotective in cerebral ischemia. Mol Med 1999;5:656-663.

-44 Koistinaho J, Miettinen S, Keinanen R, Vartiainen N, Roivainen R, Laitinen JT: Longterm induction of haem oxygenase-1 (HSP-32) in astrocytes and microglia following transient focal brain ischaemia in the rat. Eur J Neurosci 1996;8:2265-2272.

-45 Nimura T, Weinstein PR, Massa SM, Panter S, Sharp FR: Heme oxygenase-1 (HO-1) protein induction in rat brain following focal ischemia. Brain Res Mol Brain Res 1996;37:201-208.

-46 Matz P, Weinstein P, States B, Honkaniemi J, Sharp FR: Subarachnoid injections of lysed blood induce the hsp70 stress gene and produce DNA fragmentation in focal areas of the rat brain. Stroke 1996;27:504-512; discussion 513.

-47 Yoo MS, Chun HS, Son JJ, DeGiorgio LA, Kim DJ, Peng C, Son JH: Oxidative stress regulated genes in nigral dopaminergic neuronal cells: correlation with the known pathology in Parkinson's disease. Brain Res Mol Brain Res 2003;110:76-84.

-48 Takizawa S, Hirabayashi H, Matsushima K, Tokuoka K, Shinohara Y: Induction of heme oxygenase protein protects neurons in cortex and striatum, but not in hippocampus, against transient forebrain ischemia. J Cereb Blood Flow Metab 1998;18:559-569.

-49 Doré S, Law A, Blackshaw S, Gauthier S, Quirion R: Alteration of expression levels of neuronal nitric oxide synthase and haem oxygenase-2 messenger RNA in the hippocampi and cortices of young adult and aged cognitively unimpaired and impaired Long-Evans rats. Neuroscience 2000;100:769-775.

-50 Panahian N, Yoshiura M, Maines MD: Overexpression of heme oxygenase-1 is neuroprotective in a model of permanent middle cerebral artery occlusion in transgenic mice. J Neurochem 1999;72:1187-1203.

51 Zhuang H, Kim YS, Greenberg DL, Doré S: Potential mechanism of stilbene neuroprotection. Soc Neurosc Abstr 2004;216:12.

- 52 Ferris CD, Jaffrey SR, Sawa A, Takahashi M, Brady SD, Barrow RK, Tysoe SA, Wolosker H, Baranano DE, Doré S, Poss KD, Snyder SH: Haem oxygenase-1 prevents cell death by regulating cellular iron. Nat Cell Biol 1999;1:152157.

53 Poss KD, Tonegawa S: Heme oxygenase 1 is required for mammalian iron reutilization. Proc Natl Acad Sci USA 1997;94:1091910924.
54 Quinlan GJ, Chen Y, Evans TW, Gutteridge JM: Iron signalling regulated directly and through oxygen: Implications for sepsis and the acute respiratory distress syndrome. Clin Sci (Lond) 2001;100:169-182.

55 Crapper McLachlan DR, Dalton AJ, Kruck TP, Bell MY, Smith WL, Kalow W, Andrews DF: Intramuscular desferrioxamine in patients with Alzheimer's disease. Lancet 1991;337: 1304-1308.

56 Vreman HJ, Wong RJ, Sanesi CA, Dennery PA, Stevenson DK: Simultaneous production of carbon monoxide and thiobarbituric acid reactive substances in rat tissue preparations by an iron-ascorbate system. Can J Physiol Pharmacol 1998;76:1057-1065.

57 Yoshida T, Noguchi M, Kikuchi G: The step of carbon monoxide liberation in the sequence of heme degradation catalyzed by the reconstituted microsomal heme oxygenase system. J Biol Chem 1982;257:9345-9348.

58 Alkadhi KA, Al-Hijailan RS, Malik K, Hogan YH: Retrograde carbon monoxide is required for induction of long-term potentiation in rat superior cervical ganglion. J Neurosci 2001;21: 3515-3520.

59 Verma A, Hirsch DJ, Glatt CE, Ronnett GV, Snyder SH: Carbon monoxide: A putative neural messenger. Science 1993;259:381-384.

60 Maines M: Carbon monoxide and nitric oxide homology: Differential modulation of heme oxygenases in brain and detection of protein and activity. Methods Enzymol 1996;268: 473-488.

61 Meffert MK, Haley JE, Schuman EM, Schulman H, Madison DV: Inhibition of hippocampal heme oxygenase, nitric oxide synthase, and long-term potentiation by metalloporphyrins. Neuron 1994;13:1225-1233.

62 Poss KD, Thomas MJ, Ebralidze AK, O’Dell TJ, Tonegawa S: Hippocampal long-term potentiation is normal in heme oxygenase- $2 \mathrm{mu}-$ tant mice. Neuron 1995; 15:867-873.

63 Linden DJ, Narasimhan K, Gurfel D: Protoporphyrins modulate voltage-gated Ca current in AtT-20 pituitary cells. J Neurophysiol 1993; 70:2673-2677.

64 Cowan RL, Doré S: Toxicity and neuroprotective effects of carbon monoxide: Consequences to suicide and survival. Encycl Psychol Behav Sci 2004;3:994-997.

65 Hartsfield CL: Cross talk between carbon monoxide and nitric oxide. Antioxid Redox Signal 2002;4:301-307.

66 Wang R, Wu L: The chemical modification of $\mathrm{KCa}$ channels by carbon monoxide in vascular smooth muscle cells. J Biol Chem 1997;272: 8222-8226.

67 Wu L, Cao K, Lu Y, Wang R: Different mechanisms underlying the stimulation of $\mathrm{K}(\mathrm{Ca})$ channels by nitric oxide and carbon monoxide. J Clin Invest 2002;110:691-700.

68 Otterbein LE: Carbon monoxide: Innovative anti-inflammatory properties of an age-old gas molecule. Antioxid Redox Signal 2002;4:309319.
69 Brouard S, Berberat PO, Tobiasch E, Seldon MP, Bach FH, Soares MP: Heme oxygenase-1derived carbon monoxide requires the activation of transcription factor NF-kappa B to protect endothelial cells from tumor necrosis factor-alpha-mediated apoptosis. J Biol Chem 2002;277:17950-17961.

-70 Gopinathan V, Miller NJ, Milner AD, RiceEvans CA: Bilirubin and ascorbate antioxidant activity in neonatal plasma. FEBS Lett 1994; 349:197-200.

71 Stocker R, Glazer AN, Ames BN: Antioxidant activity of albumin-bound bilirubin. Proc Natl Acad Sci USA 1987;84:5918-5922.

72 Farrera JA, Jauma A, Ribo JM, Peire MA, Parellada PP, Roques-Choua S, Bienvenue E, Seta P: The antioxidant role of bile pigments evaluated by chemical tests. Bioorg Med Chem 1994;2:181-185.

-73 Doré S, Takahashi M, Ferris CD, Zakhary R, Hester LD, Guastella D, Snyder SH: Bilirubin, formed by activation of heme oxygenase-2, protects neurons against oxidative stress injury. Proc Natl Acad Sci USA 1999;96:24452450.

74 Doré S, Snyder SH: Neuroprotective action of bilirubin against oxidative stress in primary hippocampal cultures. Ann NY Acad Sci 1999; 890:167-172.

75 Takahashi M, Doré S, Ferris CD, Tomita T, Sawa A, Wolosker H, Borchelt DR, Iwatsubo T, Kim SH, Thinakaran G, Sisodia SS, Snyder SH: Amyloid precursor proteins inhibit heme oxygenase activity and augment neurotoxicity in Alzheimer's disease. Neuron 2000;28:461473.

76 Kimpara T, Takeda A, Yamaguchi T, Arai H, Okita N, Takase S, Sasaki H, Itoyama Y: Increased bilirubins and their derivatives in cerebrospinal fluid in Alzheimer's disease. Neurobiol Aging 2000;21:551-554.

77 Zhuang H, Kim YS, Namiranian K, Doré S: Prostaglandins of J series control heme oxygenase expression: Potential significance in modulating neuroinflammation. Ann N Y Acad Sci 2003;993:208-216.

78 Bishop A, Cashman NR: Induced adaptive resistance to oxidative stress in the CNS: A discussion on possible mechanisms and their therapeutic potential. Curr Drug Metab 2003;4: 171-184.

79 Goto S, Sampei K, Alkayed NJ, Doré S, Koehler RC: Characterization of a new doublefilament model of focal cerebral ischemia in heme oxygenase-2-deficient mice. Am J Physiol Regul Integr Comp Physiol 2003;285:R222R230.

80 Doré S, Goto S, Sampei K, Blackshaw S, Hester LD, Ingi T, Sawa A, Traystman RJ, Koehler RC, Snyder SH: Heme oxygenase-2 acts to prevent neuronal cell death in brain cultures and following transient cerebral ischemia. Neuroscience 2000;99:587-592.

81 Calabrese V, Butterfield DA, Stella AM: Nutritional antioxidants and the heme oxygenase pathway of stress tolerance: Novel targets for neuroprotection in Alzheimer's disease. Ital J Biochem 2003;52:177-181. 
82 Schipper HM, Cisse S, Stopa EG: Expression of heme oxygenase-1 in the senescent and Alzheimer-diseased brain. Ann Neurol 1995;37: 758-768.

83 Wagner KR, Sharp FR, Ardizzone TD, Lu A, Clark JF: Heme and iron metabolism: Role in cerebral hemorrhage. J Cereb Blood Flow Metab 2003;23:629-652.

84 Thompson K, Menzies S, Muckenthaler M, Torti FM, Wood T, Torti SV, Hentze MW, Beard J, Connor J: Mouse brains deficient in $\mathrm{H}$-ferritin have normal iron concentration but a protein profile of iron deficiency and increased evidence of oxidative stress. J Neurosci Res 2003;71:46-63.

85 Krieger J, Schroeder C: Iron, brain and restless legs syndrome. Sleep Med Rev 2001;5:277286.

86 Ponka P: Hereditary causes of disturbed iron homeostasis in the central nervous system. Ann NY Acad Sci 2004;1012:267-281.

88 Xu X, Pin S, Gathinji M, Fuchs R, Harris ZL: Aceruloplasminemia: An inherited neurodegenerative disease with impairment of iron homeostasis. Ann NY Acad Sci 2004; 1012:299305.

88 Crompton DE, Chinnery PF, Fey C, Curtis AR, Morris CM, Kierstan J, Burt A, Young F, Coulthard A, Curtis A, Ince PG, Bates D, Jackson MJ, Burn J: Neuroferritinopathy: A window on the role of iron in neurodegeneration. Blood Cells Mol Dis 2002;29:522-531.
89 Reid G: Association of sudden infant death syndrome with grossly deranged iron metabolism and nitric oxide overload. Med Hypotheses 2000;54:137-139.

90 Artinian LR, Ding JM, Gillette MU: Carbon monoxide and nitric oxide: Interacting messengers in muscarinic signaling to the brain's circadian clock. Exp Neurol 2001;171:293300.

91 Dioum EM, Rutter J, Tuckerman JR, Gonzalez G, Gilles-Gonzalez MA, McKnight SL: NPAS2: a gas-responsive transcription factor. Science 2002;298:2385-2387.

92 Ilzecka J, Stelmasiak Z: Serum bilirubin concentration in patients with amyotrophic lateral sclerosis. Clin Neurol Neurosurg 2003;105: 237-240.

93 Gordh T, Sharma HS, Azizi M, Alm P, Westman J: Spinal nerve lesion induces upregulation of constitutive isoform of heme oxygenase in the spinal cord. An immunohistochemical investigation in the rat. Amino Acids 2000;19: 373-381.

94 Beschorner R, Adjodah D, Schwab JM, Mittelbronn M, Pedal I, Mattern R, Schluesener HJ, Meyermann R: Long-term expression of heme oxygenase-1 (HO-1, HSP-32) following focal cerebral infarctions and traumatic brain injury in humans. Acta Neuropathol (Berl) 2000;100:377-384.

95 Browne SE, Ferrante RJ, Beal MF: Oxidative stress in Huntington's disease. Brain Pathol 1999;9:147-163.

96 Cooke RW: New approach to prevention of kernicterus. Lancet 1999;353:1814-1815.
97 Hara E, Takahashi K, Tominaga T, Kumabe T, Kayama T, Suzuki H, Fujita H, Yoshimoto T, Shirato K, Shibahara S: Expression of heme oxygenase and inducible nitric oxide synthase mRNA in human brain tumors. Biochem Biophys Res Commun 1996;224:153158.

-98 Solowiej E, Kasprzycka-Guttman T, Fiedor P, Rowinski W: Chemoprevention of cancerogenesis - the role of sulforaphane. Acta $\mathrm{Pol}$ Pharm 2003;60:97-100.

-99 Liang DY, Li X, Clark JD: Formalin-induced spinal cord calcium/calmodulin-dependent protein kinase II alpha expression is modulated by heme oxygenase in mice. Neurosci Lett 2004;360:61-64.

100 Carratu P, Pourcyrous M, Fedinec A, Leffler $\mathrm{CW}$, Parfenova H: Endogenous heme oxygenase prevents impairment of cerebral vascular functions caused by seizures. Am J Physiol 2003;285:H1148-H1157.

101 Zhuang H, Littleton-Kearney MT, Doré S: Characterization of heme oxygenase in adult rodent platelets. Curr Neurovasc Res 2004; in press.

102 Law A, Doré S, Blackshaw S, Gauthier S, Quirion R: Alteration of expression levels of neuronal nitric oxide synthase and haem oxygenase-2 messenger RNA in the hippocampi and cortices of young adult and aged cognitively unimpaired and impaired Long-Evans rats. Neuroscience 2000;100:769-775. 